\title{
CONNECTICUT WARBLER CLUTCHES FROM SASKATCHEWAN: UNCERTAIN STATUS AND AN ABNORMALLY PIGMENTED CLUTCH
}

TODD J. UNDERWOOD, Department of Biology, Kutztown University, Kutztown, PA 19530, USA, <E-mail: underwoo@kutztown.edu>; SPENCER G. SEALY, Department of Biological Sciences, University of Manitoba, Winnipeg, MB R3T2N2; and GLENN C. SUTTER, Life Sciences, Royal Saskatchewan Museum, Regina, SK S4S0A2

Connecticut Warblers are one of the most sought-after wood warblers by birders because of their shy habits and remote breeding habitat. Despite the interest by birders, Connecticut Warblers remain one of the least-known breeding birds in North America and have garnered little direct scientific study. ${ }^{21}$ This lack of knowledge and proximity to their breeding range while at the University of Manitoba led the senior author to begin an investigation into the breeding records of Connecticut Warblers in the prairie provinces. The three nest records from the Duck Mountain area of Saskatchewan reported in Houston and Anaka's recent book Birds of Yorkton - Duck Mountain ${ }^{11}$ captured our interest, especially because one was reported to have been parasitized by a Brownheaded Cowbird. An investigation of these specimens in the Royal Saskatchewan Museum (RSM) revealed that these nests are even more noteworthy than Houston and Anaka initially reported. ${ }^{11}$ Here we present additional details regarding the Connecticut Warbler nests from the Duck Mountain area to clarify the status of the records, investigate the first possible record of Brown-headed Cowbird parasitism on this species, and note an abnormally pigmented clutch.

Houston and Anaka reported that Fred W. Lahrman collected three nests of the Connecticut Warbler at Madge
Lake from the Saskatchewan Museum of Natural History's field camp on 29 June 1951. ${ }^{11}$ The nests and eggs were identified by the following RSM catalogue numbers: \#5511, \#11667, and \#11765. The contents of nest \#5511 were listed as "with four young," whereas nests \#11667 and \#11765 were listed as containing "3 eggs and 1 cowbird egg." 11 An inspection of these clutches in the RSM collection revealed that some of the information reported by Houston and Anaka ${ }^{11}$ conflicts with the specimens and museum records. The RSM's computer database lists all three of these nests and clutches, but only two clutches, \#11667 and \#11765, were located in the collection. All of the nests and clutch \#5511 are missing from the museum collection. Strangely, only the contents of \#11667 (two warbler eggs plus one cowbird egg; Fig. 1) seem to match the specimens, the museum's computer database, and Houston and Anaka's account. ${ }^{11}$ The description of a clutch containing three eggs and one cowbird may be interpreted by some collectors/ornithologists to indicate a total of three eggs with one of the three being a cowbird egg. These discrepancies led us to examine the original documentation of these putative Connecticut Warbler nests and to carefully consider their validity as nest records for Saskatchewan.

Unfortunately, we could not find any original field notes, nest cards, or 


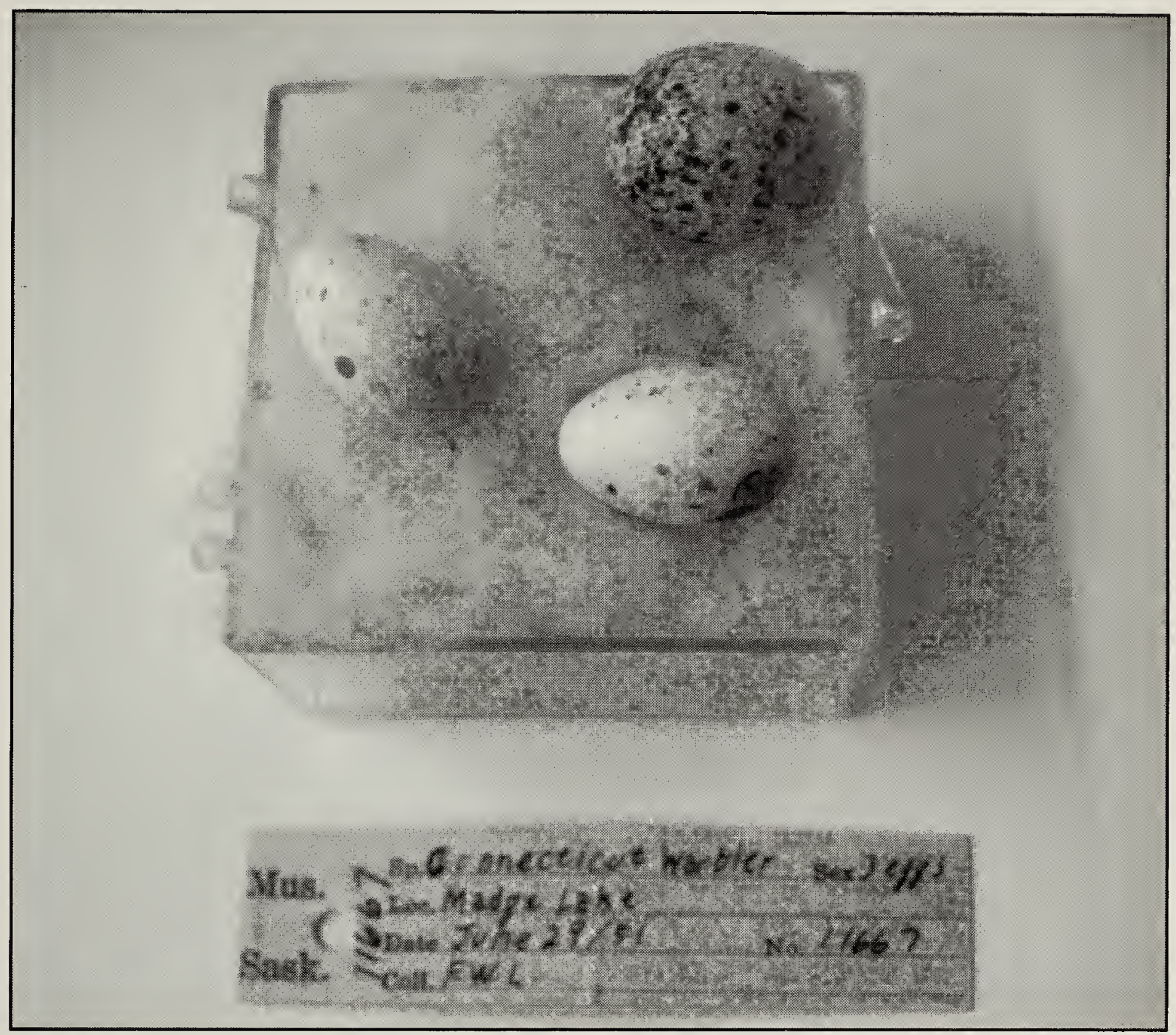

Figure 1. A putative Connecticut Warbler clutch (RSM \#11667) with a cowbird egg collected 29 June 1951 by Fred W. Lahrman at Madge Lake, SK.

Mélanie F. Guigueno

summaries of field notes that included a description or mention of Connecticut Warbler nests from Madge Lake. In an unpublished copy of Lahrman's bird list and a bird list published in Blue Jay from Madge Lake in 1951, oddly there is no mention of Connecticut Warblers. ${ }^{2}$ The only original published documentation of Connecticut Warbler nests in Saskatchewan was given in Bard's annual report for the museum that lists two Connecticut Warbler nests and eggs (\#5428 and \#5511 - each with 3 eggs) as acquisitions by the museum in 1951-1952. ${ }^{4}$ Examination of the museum's original hand-written accession catalogue and typed catalogue summary cards only add to the confusion. These records both list nests \#5428 and \#5511 with three eggs and one cowbird egg and note that a female was collected with each nest. The records for nest \#11765 show that the contents, " 1 nest and 4 eggs of Connecticut Warbler," match the specimen (Fig. 2), although the date is incorrectly listed as 9 June 1951 on the catalogue summary card. However, the records for nest \#11667 give its contents as " 1 egg and nest of Connecticut Warbler (plus 2 cowbird eggs)." The specimen label for clutch \#11667 also states a female was collected with this clutch. Houston and Anaka may have reported the contents of nests \#11667 and \#11765 from data associated with the catalogue summary cards for nests 


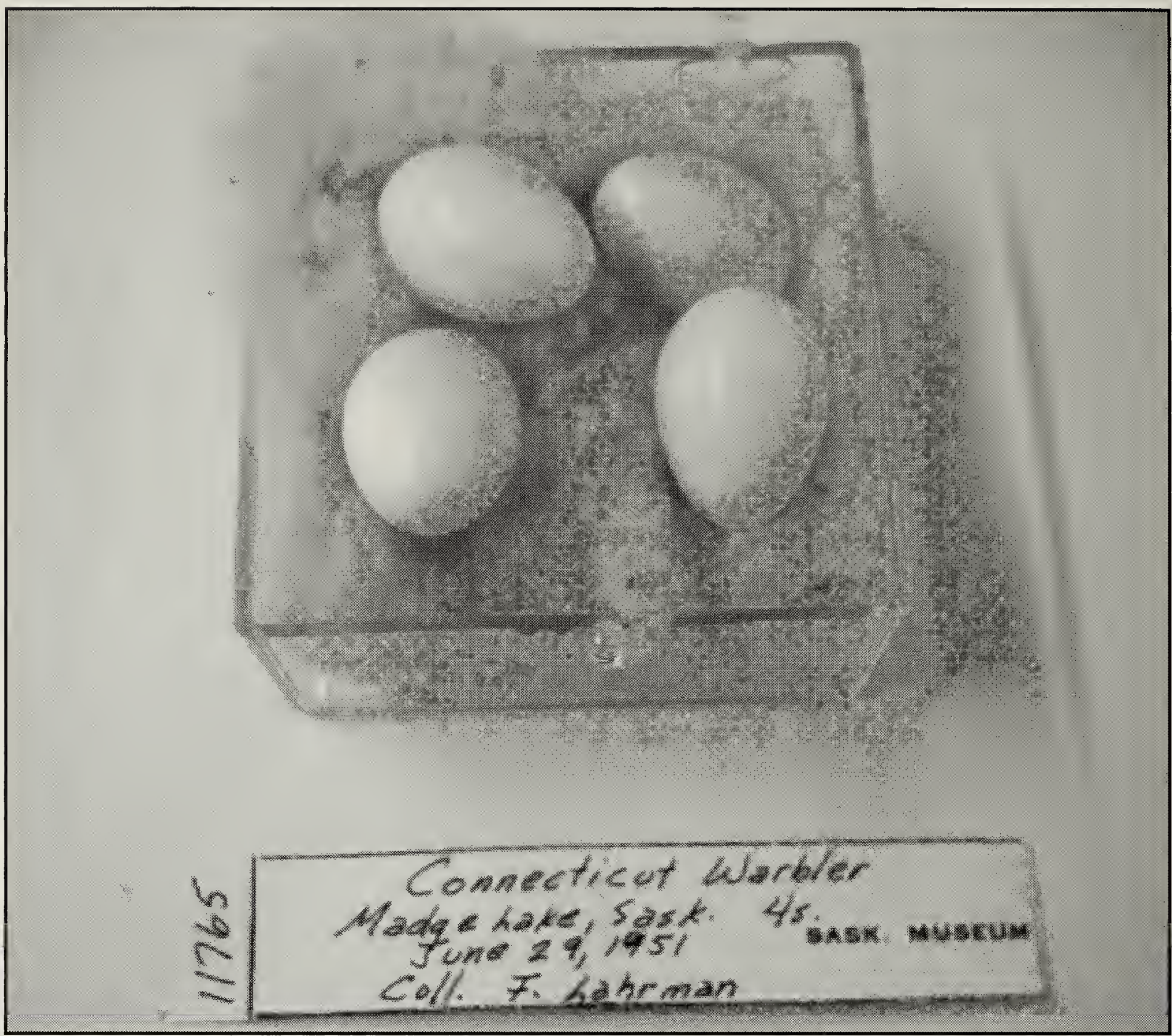

Figure 2. A putative Connecticut Warbler clutch (RSM \#11765) with four immaculate white eggs collected 29 June 1951 by Fred W. Lahrman at Madge Lake, SK.

Mélanie F. Guigueno

\#5428 and \#5511. ${ }^{11}$ The statement of nest \#5511 containing four young in the Birds of Yorkton-Duck Mountain was an error (C. S. Houston, pers. comm.). There is no current record in the RSM's computer database or specimen collection of nest/ clutch \#5428.

It seems unlikely that there ever was a total of four Connecticut Warbler nests and/or clutches held in the museum (\#s $5428,5511,11667,11765)$. The lack of any recent documentation or of a specimen for nest \#5428 and the lack of a specimen to match nest \#5511 led us to the simplest explanation for the confusion surrounding these nests - there were only two Connecticut Warbler nests with clutches (\#5428 and \#5511) collected at Madge Lake, and these were renumbered at a later date. All specimens reported as accessioned by the museum from 19511952 were given catalogue numbers in the 5000's, which supports a later renumbering. Thus, it appears that the two Connecticut Warbler clutches in the RSM collection today (Figs. 1 and 2) were most likely first accessioned as \#5428 and \#5511 in 1951 and were later renumbered as \#11667 and \#11765. This scenario is supported by C. S. Houston (pers. comm.) who also had examined the specimens and much of the information associated with them. Unfortunately, we cannot link the earlier specimen numbers to specific later numbers because the original 
accession catalogue and catalogue cards report the same contents for the two nests. Because of the inconsistent reporting of the contents of these two nests, we must assume that the current contents are correct and that they likely have been incorrectly reported over the years. Similar transcription errors and confusion over specimens have occurred when other collections have been renumbered. ${ }^{12}$

If clutch \#11667 contains a Brownheaded Cowbird egg, this would represent the first record of parasitism on the Connecticut Warbler. ${ }^{9,16,17}$ Clutch \#11667 contains two warbler eggs and one cowbird egg (Fig. 1), which Lahrman collected along with the adult female warbler (as listed on the specimen label for the eggs). A museum skin of this female (\#10261/A2113) is present in the RSM collection (Fig. 3, see inside front cover). This specimen was likely prepared in the field, given that it is a flat skin, but its high accession number $(>5000)$ indicates that it was not officially added to the museum collection until a later date. More interestingly, this skin does not appear to be a Connecticut Warbler. The plumage does not clearly match that of a female Connecticut Warbler, and measurements confirm this. Lanyon and Bull developed a measurement formula, wing (flat) - tail length, that clearly separates the three similar warblers in the genus Oporornis (Connecticut, Mourning, and MacGillivray's warblers). ${ }^{15}$ A wing-tail difference of $>18 \mathrm{~mm}$ indicates a Connecticut Warbler, whereas a wingtail difference of $10-18 \mathrm{~mm}$ indicates a Mourning Warbler.15 Our measurements revealed a wing-tail difference of 12.5 $\mathrm{mm}$ (flat wing $=59.5 \mathrm{~mm}$ and tail $=47$ $\mathrm{mm}$ ), which is approximately the average difference for a female Mourning Warbler but well below the wing-tail difference of a female Connecticut Warbler. Clearly, this is the skin of a female Mourning Warbler.
The dimensions of the two warbler eggs average $19.7 \mathrm{~mm} \times 13.4 \mathrm{~mm}$, which is within the range reported for both Connecticut Warblers ${ }^{21}$ and Mourning Warblers. ${ }^{20}$ Based on the evidence from the female collected with this nest, we conclude that this nest and eggs belong to a Mourning Warbler, not a Connecticut Warbler.

It is not surprising that this female and clutch were misidentified. Connecticut and Mourning Warbler females ${ }^{15}$ and eggs resemble each other closely, ${ }^{21}$ and the nest placement and breeding habitats of these species may be similar. ${ }^{20,21}$ This misidentification is a good example of the importance of scientific collecting and proper documentation of distributional records. ${ }^{1}$ The lack of a Connecticut Warbler in Lahrman's list of birds from Madge Lake may indicate that he was uncertain about the identification of the female warbler specimen and these nests. Lahrman was a well-regarded field naturalis $\mathrm{t}^{22}$ who documented other rare bird observations, such as an extralimital nesting record of a Common Redpoll ${ }^{14}$ and a possible Eskimo Curlew sighting. ${ }^{13}$ If he were certain of this identification, he likely would have included it in his bird list and perhaps would have documented this first nest record for Saskatchewan in Blue Jay.

The cowbird egg in clutch \#11667 clearly differs in appearance from the warbler eggs and matches the general colour and spot pattern of a cowbird egg. The dimensions of the egg measured $22.6 \times 17.3 \mathrm{~mm}$ and are well within the normal range of those of a Brown-headed Cowbird egg $(18.1 \times 14.3 \mathrm{~mm}$ to $23.7 \times$ $18.8 \mathrm{~mm}$; S.G. Sealy, unpublished data) but are outside the upper size limit (21.3 $\times 15.6 \mathrm{~mm}$ ) of a Connecticut or Mourning Warbler egg. ${ }^{20,21}$ Thus, we conclude this is a cowbird egg and a record of cowbird parasitism on a Mourning Warbler nest. 
Mourning Warblers are considered uncommon hosts of the Brown-headed Cowbird, 8 but there are several records of parasitism on this warbler. ${ }^{8,9}$

The apparent misidentification of clutch \#11667 necessitates a careful scrutiny of the other clutch from Madge Lake. Clutch \#11765 contains four warbler eggs, all of which are white and have no other markings on them (Fig. 2). Connecticut Warbler eggs typically are white or cream-coloured with numerous spots in various shades of brown. ${ }^{21}$ There are no records of Connecticut Warblers laying immaculate white eggs, ${ }^{21}$ which also suggests this nest and eggs may have been incorrectly identified. Immaculate white eggs are rare in North American warblers. Most species of warblers lay white to off-white eggs with spots. ${ }^{3}$ Only two species regularly lay immaculate white eggs: Bachman's Warbler and Swainson's Warbler. ${ }^{3}$ Both species are ground-nesting warblers, like Connecticut Warblers, but are highly unlikely breeders in Saskatchewan (the ranges of both are in the southern United States, and Bachman's Warbler is believed to be extinct). The four eggs averaged 20.1 $\mathrm{mm} \times 14.4 \mathrm{~mm}$, which is well within the range of dimensions for Connecticut Warbler eggs, ${ }^{21}$ but above the upper size limit for Mourning Warbler eggs. ${ }^{20}$ We know of no other ground-nesting bird in this region that typically lays immaculate white eggs that could be confused with those of a Connecticut Warbler. The egg measurements, however, match the relative size of a few species of ground nesters found in habitat similar to that used by the Connecticut Warbler in the Duck Mountain area. These include Northern Waterthrush, Lincoln's Sparrow, Swamp Sparrow, and Dark-eyed Junco. Of these possible alternate species, only Dark-eyed Juncos are known to occasionally lay immaculate white eggs. ${ }^{19}$ Other than egg dimensions and habitat similarities, there is no evidence to suggest this clutch belongs to one of these species. The original accession catalogue and summary cards for the early Connecticut Warbler nest specimens (\#s 5428 and 5511) indicate a female was collected with each nest and clutch. However, the specimen label for \#11765 does not indicate that a female was collected with this clutch, and there is no other specimen of a female Connecticut Warbler from Madge Lake in the RSM collection. We believe the statement regarding the collection of a second female Connecticut Warbler is likely an error. Based on the misidentification of clutch \#11667, abnormal pigmentation, and lack of additional evidence, we conclude that clutch \#11765 is possibly that of a Connecticut Warbler, but cannot confirm its identity.

Pure white or immaculate eggs appearing as a single egg in a clutch or as entire clutches are uncommon among birds that typically lay pigmented eggs. ${ }^{10}$ Entire clutches of immaculate eggs appear to be quite rare among warblers that lay spotted eggs and have only been documented in Pine Warblers, Prothonotary Warblers, and Yellowbreasted Chats. $5,10,18$ There are also a few records of other warblers (Blue-winged Warblers, Nashville Warblers, Northern Parulas, American Redstarts) laying nearly immaculate white eggs. ${ }^{5}$ The loss of colour in pigmented eggs from domestic poultry has been attributed to infections, use of antibiotics, dehydration, and stress. ${ }^{7}$ However, the cause of pigment loss from the eggshells of wild birds is not clear. Based on the observation of a banded female Yellow-breasted Chat that laid normally spotted eggs in one year and immaculate white eggs in the next two years, McKibbin and Bishop suggested that some environmental trigger may have led to the loss of pigmentation from these warbler eggs. ${ }^{18}$ There is no 
information associated with this putative Connecticut Warbler clutch that would allow us to speculate on the cause of pigment loss from these eggs.

In conclusion, we have clarified the status of the only putative records of Connecticut Warblers nesting in Saskatchewan. To the best of our knowledge, there were only two putative Connecticut Warbler nests found near Madge Lake and two nests and clutches deposited in the RSM. The nests are now missing, but two clutches remain in the museum collection (Figs. 1 and 2). Uncertainty surrounding the number of nests and their contents is most likely due to inaccurate record keeping over the years since they were collected. More importantly, one of these nests and clutches (\#11667) was misidentified and is clearly that of a Mourning Warbler. There is a cowbird egg in this clutch, but this does not add a new host to those known for the Brownheaded Cowbird. The second clutch is abnormally pigmented for a Connecticut Warbler and there is no additional evidence to confirm its identification, which leads us to suggest this must be considered a possible but unusual and unconfirmed nest of the Connecticut Warbler. Specific identification of these eggs would require a genetic-based test on eggshell membrane material left behind when the contents were removed, such as the test used by Chilton and Sorenson to confirm the identity of the putative eggs of the extinct Labrador Duck. ${ }^{6}$ Based on our assessment of the current evidence surrounding these two Connecticut Warbler clutches, the status of Connecticut Warbler nest records in Saskatchewan should be considered possible but unconfirmed.

\section{Acknowledgements}

We thank Mélanie F. Guigueno for taking photographs of the eggs and $\mathrm{C}$.
Stuart Houston and Robert W. Nero for comments on the manuscript. Houston also provided a copy of Lahrman's unpublished bird list from Madge Lake, copies of two annual reports published by the Saskatchewan Museum of Natural History in the 1950s, and additional copies of museum data. We also thank the Royal Saskatchewan Museum for access to the museum collection and data. Our studies of cowbirds and their hosts are funded by a grant from the Natural Sciences and Engineering Research Council of Canada to Spencer Sealy.

1. AMERICAN ORNITHOLOGISTS' UNION. 1998. Check-list of North American birds, 7th edition. American Ornithologists' Union, Washington D.C.

2. ANONYMOUS. 1956. Birds of Madge Lake. Blue Jay 14:53-54.

3. BAICICH, P. J., and C. J. O. HARRISON. 1997. A guide to the nests, eggs, and nestlings of North American birds, second edition. Academic Press, San Diego, California.

4. BARD, F. G. 1953. Annual report of the Provincial Museum of Natural History. In: Annual Report of the Department of Natural Resources, 1952-1953. p. 103-116.

5. BENT, A. C. 1953. Life histories of North American wood warblers. United States National Museum, Bulletin 203. Smithsonian Institution, Washington, D.C.

6. CHILTON, G., and M. D. SORENSON. 2007. Genetic identification of eggs purportedly from the extinct Labrador Duck (Camptorhynchus labradorius). Auk 124:962-968.

7. DHAWALE, A. 2008. Abnormal eggs cause subnormal profits. World Poultry 24:20-23

8. FRIEDMANN, H. 1963. Host relations of the parasitic cowbirds. United States National Museum Bulletin No. 233, Smithsonian Institution, Washington, D.C.

9. FRIEDMANN, H., and L. F. KIFF. 1985. The parasitic cowbirds and their hosts. Proceedings of the Western Foundation of Vertebrate Zoology 2:225-304.

10. GROSS, A. O. 1968. Albinistic eggs (white eggs) of some North American birds. Bird-Banding $39: 1-6$. 
11. HOUSTON, C. S., and W. ANAKA. 2003. Birds of Yorkton-Duck Mountain. Special Publication No. 24, Callin Series No. 6, Saskatchewan Natural History Society, Regina.

12. HOUSTON, C. S., and K. J. MCGOWAN. 1999. The westward spread of the Barred Owl. Blue Jay 57:190-195.

13. LAHRMAN, F. W. 1972. A rare observation of the Eskimo Curlew. Blue Jay 30:87-88.

14. LAHRMAN, F. W., and R. W. NERO. 1961. A Common Redpoll nest record for southern Saskatchewan. Blue Jay 19:113-114.

15. LANYON, W. E., and J. BULL. 1967. Identification of Connecticut, Mourning, and MacGillivray's Warblers. Bird-Banding 38:187-194.

16. LOWTHER, P. E. 1993. Brown-headed Cowbird (Molothrus ater). In: Poole, A. and F. Gill (eds.) The Birds of North America, No. 47. The Academy of Natural Sciences, Philadelphia, Pennsylvania, and The American Ornithologists' Union, Washington, D.C.

17. LOWTHER, P. E. 2009. Lists of victims and hosts of the parasitic cowbirds (Molothrus), version: 16 Feb 2009. http://fm1.fieldmuseum.org/aa/Files/lowther/ CBList.pdf. Accessed 3 March 2009.

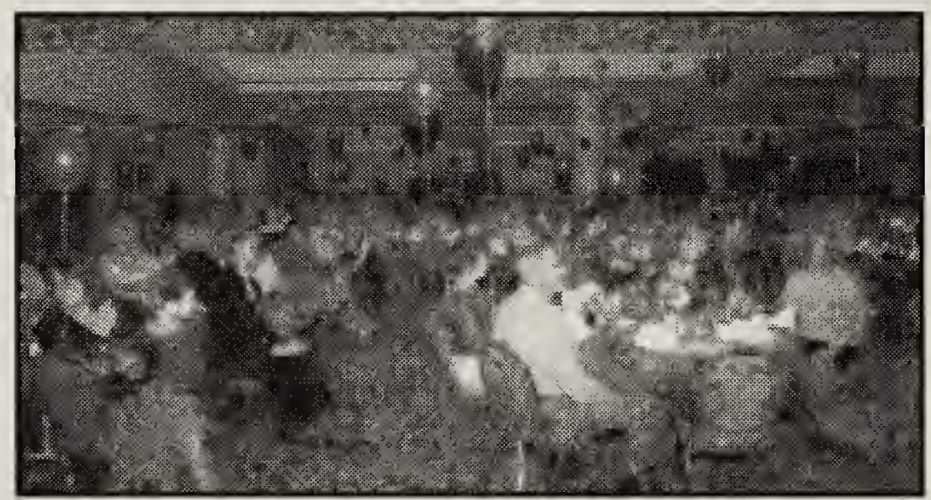

60th anniversary of Nature Saskatchewan, Friday evening Gala dinner. The balloons in the background were part of a fundraising raffle for two Robert Bateman prints and two Robert Bateman books.

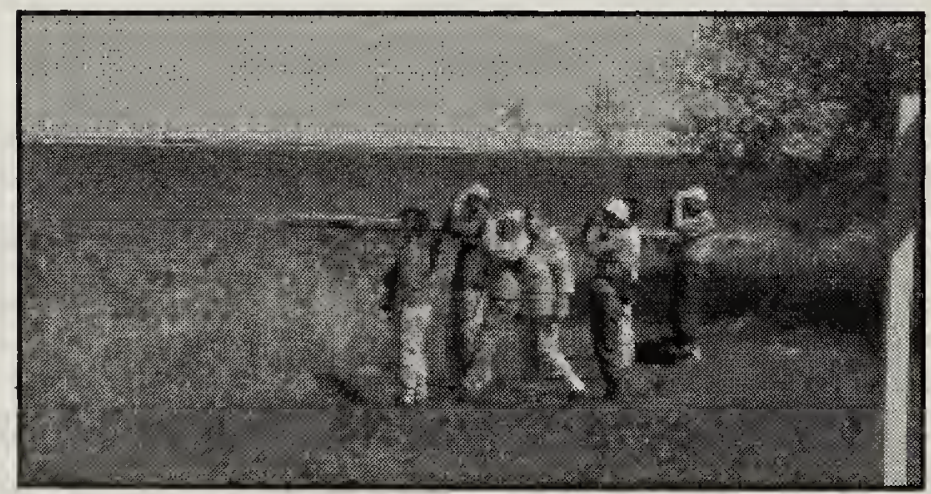

Trevor Herriot leading a tour at the Spring Meet
18. MCKIBBIN, R., and C. A. BISHOP. 2008. Unusual colour of eggs of a female western Yellow-breasted Chat in the south Okanagan Valley, British Columbia, Canada. British Columbia Birds 18:23-24.

19. NOLAN, V., Jr., E. D. KETTERSON, D. A. CRISTOL, C. M. ROGERS, E. D. CLOTFELTER, R. C. TITUS, S. J. SCHOECH and E. SNAJDR. 2002 Dark-eyed Junco (Junco hyemalis). In: Poole, A and F. Gill (eds.) The Birds of North America, No. 716. The Birds of North America, Inc., Philadelphia, Pennsylvania.

20. PITOCCHELLI, J. 1993. Mourning Warbler (Oporornis philadelphia). In: Poole, A. and F. Gill (eds.) The Birds of North America, No. 72. The Academy of Natural Sciences, Philadelphia, Pennsylvania, and The American Ornithologists' Union, Washington, D. C.

21. PITOCCHELLI, J., J. BOUCHIE, and D. JONES. 1997. Connecticut Warbler (Oporornis agilis). In: Poole, A. and F. Gill (eds.) The Birds of North America, No. 320. The Academy of Natural Sciences, Philadelphia, Pennsylvania, and The American Ornithologists' Union, Washington, D. C.

22. SCOTT, L. 2003. Fred W. Lahrman, 1921-2003. Blue Jay 61:186-188.

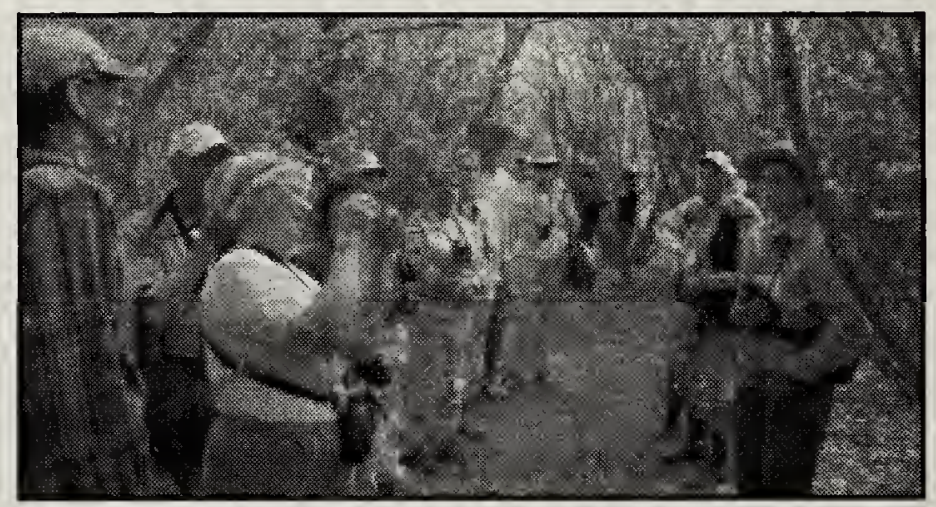

60th anniversary of Nature Saskatchewan: mist-netting at the Last Mountain Bird Observatory.

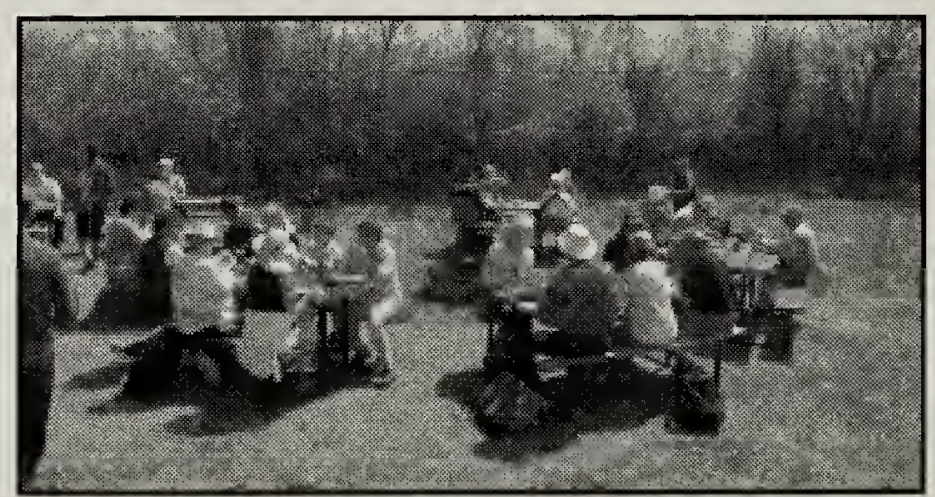

Lunch at the Last Mountain Regional Park between field trips 